\title{
Micronutrients Impact on Soybean (Glycine max (Merrill)) Qualitative and Quantitative Traits
}

\author{
Esmaeil Yasari (Corresponding author) \\ Agriculture Department, Payame Noor University \\ 19395-4697, Tehran, Iran \\ E-mail: e_yassari@yahoo.com
}

Abed Vahedi

Department of Agronomy and Plant Breeding

Faculty of Agricultural and Natural Resources

Islamic Azad University, Qaemshahr Branch, Iran

Received: May 13, 2011

Accepted: May 26, 2011 Published: April 1, 2012

doi:10.5539/ijb.v4n2p112

URL: http://dx.doi.org/10.5539/ijb.v4n2p112

\begin{abstract}
In order to study the effects of applying the micronutrients zinc, manganese, and boron, and to compare the effects that incorporating them in the soil and spraying them on the crop on seed oil and protein contents and percentages, a study was conducted based on the factorial design with the two factors of incorporating these micronutrients in the soil and spraying them on the crop, in 16 treatments and four replications (a total of 64 trials), in 2009-2010 in Dasht-e-Naz in Sari of northern Iran. The treatments were as follows: T1=control, $\mathrm{T} 2=\mathrm{Znf}, \mathrm{T} 3=\mathrm{Mnf}, \mathrm{T} 4=\mathrm{Bf}, \mathrm{T} 5=\mathrm{Zns}, \mathrm{T} 6=\mathrm{Zns}+\mathrm{Bf}, \mathrm{T} 7=\mathrm{Zns}+\mathrm{Mnf}, \mathrm{T} 8=\mathrm{Zns}+\mathrm{Znf}, \mathrm{T} 9=\mathrm{Mns}, \mathrm{T} 10=\mathrm{Mns}+\mathrm{Bf}$, $\mathrm{T} 11=\mathrm{Mns}+\mathrm{Mnf}, \mathrm{T} 12=\mathrm{Mns}+\mathrm{Znf}, \mathrm{T} 13=\mathrm{Bs}, \mathrm{T} 14=\mathrm{Bs}+\mathrm{Bf}, \mathrm{T} 15=\mathrm{Bs}+\mathrm{Mns}, \mathrm{T} 16=\mathrm{Bs}+\mathrm{Znf}$. Results obtained showed that the highest seed oil percentage $(25.03 \%)$ was achieved by spraying zinc on the crop, and that the biggest seed oil yield (359.31 Kg.h) was obtained by applying manganese to the soil. Results of the comparison of the means indicated that the highest seed protein content $(36.12 \%)$ was achieved by spraying boron on the crop, and the greatest seed protein yield $(545.54 \mathrm{Kg} . \mathrm{h})$ was obtained when manganese was added to the soil. These results also showed that the largest number of total pods per plant (71.05), and the biggest seed yield (152.9 g.m $\left.\mathrm{m}^{-2}\right)$ were achieved by applying manganese to the soil. In the comparison of the interaction effects of the data, it was also shown that, although the highest seed oil percentage belonged to the spraying of zinc on the crop, yet the greatest seed yield among all the treatments $\left(170.7 \mathrm{~g} . \mathrm{m}^{-2}\right)$ was that of the treatment of adding manganese to the soil plus spraying zinc on the crop, in which the greatest number of pods per plant (77.87) and the highest seed protein yield (631.1 Kg.h) and the highest seed oil yield (284.5 Kg.h) were obtained.
\end{abstract}

Keywords: Boron, Manganese, Oil, Protein, Soybean, Zinc

\section{Introduction}

Excessive application of macronutrient fertilizers, such as nitrogen and phosphorus, the fact that micronutrients are not used in crop production in Mazandaran, and also the calcareous nature of soils in the fields of eastern Mazandaran, have resulted in micronutrient deficiencies. Study of the trend of fertilizer application in the past decade reveals that more than 90 percent of the fertilizers applied during this period were nitrogen and phosphorous fertilizers, with the ratio of $\mathrm{N}, \mathrm{P}, \mathrm{K}$, and $\mathrm{S}$ fertilizers to fertilizers containing micronutrients being 100, 68, 4.5, and 0.065, respectively (Malakouti and Tehrani, 1999). Studies carried out in east Mazandaran showed that deficiencies of these elements are one of the limiting factors in achieving the maximum seed yield and seed oil and protein yield and percentages in the prevailing crop growing conditions (Assadi and Mahmoodi, 2001). Undoubtedly, the optimal application of plant nutrients has a significant role in increasing the yield and quality of soybean and its oil. Zinc deficiency is one of the most important and widespread micronutrient deficiencies in the world, and it reduces the yield of crop plants (Grewal et al., 1997; Cakmak, 2000). Soybean is sensitive to boron deficiency (Victor et al., 1990); and boron is very influential in soybean seed formation and in 
increasing its seed oil content (Grant and Baily, 1992). Soybean is also very sensitive to manganese deficiency, a prevalent condition in neutral or alkali soil with high $\mathrm{pH}$, and this deficiency results in short plants having yellow leaves. Manganese deficiency also has a negative influence on soybean seed oil content. Alley et al., (2008) reported that adding manganese sulphate to the soil and spraying it on the crop resulted in an increase in manganese absorption and in seed and oil yield of soybean.

Since Mazandaran is the center of soybean production in the north of the country, studying the effects of micronutrients on the qualitative features of soybean seed, such as the oil and protein yields and percentages, is very important. Therefore, this study was conducted in the region of Dasht-e-Naz to investigate the effects of applying the microelements zinc, manganese, and boron (and to compare the effects of the methods of applying them -i.e., incorporating them in the soil or spraying them on the crop) on the seed oil percentage and seed oil and protein yields.

\section{Methods and Materials}

This study was carried out on the basis of the factorial experimental design with the two factors of adding the micronutrients to the soil and spraying them on the crop, with 16 treatments and 4 replications (a total of 64 trials). The treatments were as follows: $\mathrm{T} 1=$ control, $\mathrm{T} 2=\mathrm{Znf}, \mathrm{T} 3=\mathrm{Mnf}, \mathrm{T} 4=\mathrm{Bf}, \mathrm{T} 5=\mathrm{Zns}, \mathrm{T} 6=\mathrm{Zns}+\mathrm{Bf}$, $\mathrm{T} 7=\mathrm{Zns}+\mathrm{Mnf}, \mathrm{T} 8=\mathrm{Zns}+\mathrm{Znf}, \mathrm{T} 9=\mathrm{Mns}, \mathrm{T} 10=\mathrm{Mns}+\mathrm{Bf}, \mathrm{T} 11=\mathrm{Mns}+\mathrm{Mnf}, \mathrm{T} 12=\mathrm{Mns}+\mathrm{Znf}, \mathrm{T} 13=\mathrm{Bs}, \mathrm{T} 14=\mathrm{Bs}+\mathrm{Bf}$, $\mathrm{T} 15=\mathrm{Bs}+\mathrm{Mns}, \mathrm{T} 16=\mathrm{Bs}+\mathrm{Znf}$. On the basis of the soil test carried out, the required amounts of the micronutrients, including zinc ( $40 \mathrm{Kg}$ of zinc sulphate per hectare), manganese (30 Kg of manganese sulphate per hectare), and boron $(10 \mathrm{Kg}$ of boric acid per hectare) were added to the soil before seeding. In the spraying treatments, zinc and manganese $(0.3 \%)$ and boron $(0.2 \%)$ were sprayed at the start of stem elongation and at flower bud formation. At harvest, samples of the plants were taken from each plot and the yields and yield components of the different plots were statistically analyzed. After harvest, seed samples were sent to the soil and water laboratory of the Mazandaran Agriculture and Natural Resources Research Center for the determination of the percentage oil and protein contents.

\section{Results}

\subsection{Oil percentage}

Results of the analysis of the variance of the data showed that the effects of the different levels of applying the micronutrients to the soil, the effects of the different levels of spraying the micronutrients on the crop, and the interaction effects of adding the micronutrients to the soil and spraying them on the crop on seed oil percentage were significant at the one percent probability level (Table 1). Results of the comparison of the means indicated that, among the treatments of applying the micronutrients to the soil, the highest seed oil content $(23.99 \%)$ was obtained when boron was added to the soil, and that this treatment had a statistically significant difference with the others. In the treatments of adding manganese and zinc to the soil, the oil percentages observed were 23.5 and $22.73 \%$, respectively, which were higher than that of the control $(22.23 \%)$ (Table 2). These results also showed that, among the spraying treatments, the highest seed oil percentage $(25.03 \%)$ was achieved when zinc was sprayed on the crop, and this treatment had a statistically significant difference with the others. The lowest seed oil percentage was observed in the control (21.69\%) (Table 3). Results of the comparison of the means also indicated that the highest seed oil percentage $(28.5 \%)$ was obtained when zinc was sprayed on the crop, and that the least seed oil content (17.5\%) belonged to the treatment of adding manganese to the soil plus spraying boron on the crop (Figure 1).

\subsection{Oil yield}

Results of the analysis of the variance of the data showed that the effects of the different levels of applying the micronutrients to the soil, the effects of the different levels of spraying the micronutrients on the crop, and the interaction effects of applying the micronutrients to the soil and spraying them on the crop on seed oil yield were significant at the one percent probability level (Table 1). Results of the analysis of variance indicated that, among the treatments of adding the micronutrients to the soil, the highest seed oil yield (359.32 Kg.h) was obtained when manganese was added to the soil, and that this treatment had a statistically significant difference with the others. The treatments of adding zinc and boron to the soil came second and third with 321.85 and 293.39 Kg.h, respectively, while the least seed oil yield belonged to the control (249.64 Kg.h) (Table 2). These results indicated that, among the treatments of spraying the micronutrients on the crop, the highest seed oil yield (317.71 Kg.h) was achieved when manganese was sprayed on the crop, and that this treatment had a statistically significant difference with the others. The least seed oil yield (255.29 Kg.h) belonged to the control (Table 3). Results of the comparison of the mutual effects of the data showed that the highest seed oil yield (284.5 Kg.h) 
was obtained by adding manganese to the soil plus spraying zinc on the crop, and that the lowest seed oil yield (137.89 Kg.h) belonged to the control (Figure 2).

\subsection{Seed protein percentage}

Results of the analysis of the variance of the data indicated that the effects of applying different levels of the micronutrients to the soil, the effects of spraying different levels of micronutrients on the crop, and the mutual effects of adding the micronutrients to the soil and spraying them on the crop on seed protein percentage were significant at the one percent probability level (Table 1). Results of the comparison of the means showed that, among the treatments of adding the micronutrients to the soil, the highest seed protein percentage $(35.67 \%)$ was obtained when manganese was added to the soil. The treatments of adding zinc to the soil and the control came second and third with 35.45 and 35.09 percent, respectively, while the lowest seed protein percentage (32.73\%) was observed in the treatment of adding boron to the soil (Table 2). These results indicated that, among the treatments of spraying the micronutrients on the crop, the highest seed protein percentage $(36.12 \%)$ was achieved when boron was sprayed on the crop, while the lowest seed protein percentage (32.24\%) belonged to the treatment of spraying zinc on the crop (Table 3). Results of the comparison of the mutual effects of the data showed that the highest seed protein percentage $(37.21 \%)$ was obtained by spraying zinc on the crop, while the least seed protein percentage (27.2\%) was observed in the treatment of adding boron to the soil plus spraying boron on the crop (Figure 3).

\subsection{Protein yield}

Results of the analysis of the variance of the data showed that the effects of applying different levels of the micronutrients to the soil, the effects of spraying different levels of the micronutrients on the crop, and the mutual effects of adding the micronutrients to the soil and spraying them on the crop on the protein yield were significant at the one percent probability level (Table 1). Results of the comparison of the means indicated that, among the treatments of adding the micronutrients to the soil, the highest protein yield (545.54 Kg.h) was obtained when manganese was added to the soil. The treatments of adding zinc and boron to the soil came second and third with 501.97 and $400.28 \mathrm{Kg} . \mathrm{h}$, respectively, while the control had the least protein yield (397.06 Kg.h) (Table 2). Results of the comparison of the means showed that, among the treatments of spraying the micronutrients on the crop, the highest protein yield $(528.43 \mathrm{Kg} . \mathrm{h})$ was observed when zinc was sprayed on the crop, while the lowest protein yield (395.11 Kg.h) was that of the control (Table 3). Results of the comparison of the mutual effects of the data indicated that the highest protein yield $(631.1 \mathrm{Kg} . \mathrm{h})$ was observed by adding manganese to the soil plus spraying zinc on the crop, while the lowest protein yield (276.8 Kg.h) was obtained by adding boron to the soil plus spraying it on the crop (Figure 4).

\subsection{Total number of pods per plant}

Results of the analysis of the variance of the data indicated that the effects of adding different levels of the micronutrients to the soil, the effects of spraying different levels of the micronutrients on the crop, and the interaction effects on the total number of pods per plant were significant at the five percent probability level (Table 1). Results of the comparison of the means showed that, among the treatments of adding the micronutrients to the soil, the largest total number of pods per plant (71.05) was obtained when manganese was added to the soil, and that this treatment could statistically be placed in one group with the treatment of adding zinc to the soil (in which the total number of pods per plant was 66.79). The treatment of adding boron to the soil and the control, with 57.04 and 55.14 pods per plant, respectively, could statistically be placed in one group, as well (Table 2). These results also indicated that, among the treatments of spraying the micronutrients on the crop, the largest total number of pods per plant (68.33) was observed when zinc was prayed on the crop, which could statistically be placed in one group with the treatment of spraying manganese on the crop (in which the total number of pods per plant was 65.81). The lowest total number of pods per plant (56.64) was that of the control (Table 3). Results of the interaction effects of the data also indicated that the largest total number of pods per plant (77.87) among all the treatments was obtained by adding manganese to the soil plus spraying zinc on the crop., and that this treatment was statistically in one group with the treatment of adding manganese to the soil plus spraying it on the crop (in which the total number of pods per plant was 72.37). As was the case in the number of pods on the main stem, the lowest total numbers of pods per plant were observed in the treatment of adding boron to the soil plus spraying it on the crop and in the control with 42.77 and 44.43 pods per plant, respectively (Figure 5).

\subsection{Seed yield}

Results of the analysis of the variance of the data showed that the effects of applying different levels of the micronutrients to the soil, the effects of spraying different levels of the micronutrients on the crop, and their 
mutual effects on seed yield were significant at the one percent probability level (Table 1). Results of the comparison of the means indicated that, among the treatments of adding the micronutrients to the soil, the highest seed yield $\left(152.9 \mathrm{~g} . \mathrm{m}^{-2}\right)$ was obtained by adding manganese to the soil. The treatments of applying zinc and boron to the soil came second and third with 141.6 and 122.3 g.m ${ }^{-2}$, respectively. The lowest seed yield $\left(112.3 \mathrm{~g} . \mathrm{m}^{-2}\right)$ belonged to the control (Table 2). These results also showed that, among the treatments of spraying the micronutrients on the crop, the highest seed yield $\left(146.3 \mathrm{~g} . \mathrm{m}^{-2}\right)$ was obtained when zinc was sprayed on the crop, with the treatments of spraying manganese and boron on the crop coming second and third with 138.5 and 126.6 g.m $\mathrm{m}^{-2}$, respectively. Other researchers, such as Maftoon and Karimian (1988), Darajeh et al. (1991), and Cakman, I (2000), have reported similar results. The lowest seed yield (117.7 g. $\left.\mathrm{m}^{-2}\right)$ was that of the control (Table 3).

Results of the interaction effects of the data also indicated that the highest seed yield $\left(170.7 \mathrm{~g} . \mathrm{m}^{-2}\right)$ among all the treatments was achieved by adding manganese to the soil plus spraying zinc on the crop, and that this treatment could not be placed in one group with any other treatment. The treatments of adding manganese to the soil plus spraying it on the crop and of adding manganese to the soil plus spraying boron on the crop came second and third with 153 and 149 g.m $\mathrm{m}^{-2}$, respectively. The lowest seed yield $\left(88 \mathrm{~g} . \mathrm{m}^{-2}\right)$ belonged to the control (Figure 6).

\section{Conclusions}

Results of this study showed that, although the highest oil percentage (28.5\%) was achieved by spraying zinc on the crop, yet the highest seed yield $\left(170.7 \mathrm{~g} . \mathrm{m}^{-2}\right)$ among all the treatments was obtained by adding manganese to the soil plus spraying zinc on the crop, and that this treatment had the largest number of pods per plant (77.87), the highest seed protein yield (631.1 Kg.h), and the largest oil yield (284.5 Kg.h). Therefore, the treatment of adding manganese to the soil plus spraying zinc on the crop can be considered the best among all the treatments studied.

\section{Reference}

Alley, M. M., C. I. Rich, G. W. Hawkins, \& D. C. Martens. (2008). Correction of Mn Deficiency of Soybeans. Agron J., 70, 35-38. http://dx.doi.org/10.2134/agronj1978.00021962007000010009x

Cakmak, I. (2000). Possible roles of zinc in protecting plant cells from damage by reaction oxygen species. New Phyto, 146, 185-205. http://dx.doi.org/10.1046/j.1469-8137.2000.00630.x

Darjeh, Z., N. Karimian, M. Moftion., A. Abtahi, \& K. Razmi. (1991). Correlation of five Zn extraction with plant responses on highly calcareous soil of Dorood Dan Dam area. Iran Agric. Res., 10, 29-45.

Grant, C. A., \& L. D. Baily. (1990). Fertility management in canola production. Can. J. Plant Sci., 73, 651-670. http://dx.doi.org/10.4141/cjps93-087

Grewel, H. S., Z. Lu, \& R. D. Graham. (1997). Influence of subsoil zinc on dry matter production, seed yield and distribution of zinc in oilseed rape genotypes differing in zinc efficiency. Plant and Soil, 192, 181-189. http://dx.doi.org/10.1023/A:1004228610138

Maftoun, M, \& N. Karimian. (1989). Relative efficiency of two zinc sources for maize (Zea mays L.) two calcareous soils from and arid area of Iran. Agronomia, 9, 771-775. http://dx.doi.org/10.1051/agro:19890804

Malakouti, Mohammad Jaafar, and Mohammad Mehdi Tehrani. (1999). The role of micronutrients in increasing the yield and improving the quality of agricultural products (Micronutrients with Macro-influence), Tarbiyat Modarress University Publications, Tehran, Iran.

Victor, M., M. A. Shorrocks, M. A. D. Phil, \& M. I. Biol. (1990). Boron deficiency its prevention and cure. Borax Holdings Limited, London. UK. 
Table 1. Analysis of Variation of the studied traits

\begin{tabular}{|c|c|c|c|c|c|c|c|}
\hline \multirow[t]{2}{*}{$\mathrm{SOV}$} & \multirow[t]{2}{*}{ DOF } & \multicolumn{6}{|c|}{ Mean Square } \\
\hline & & Oil \% & Oil Yield & $\operatorname{Pr} \%$ & Pr Yield & Pods/Plant & Seed Yield \\
\hline Replication & 3 & $* *$ & $* *$ & ns & ns & ns & ns \\
\hline $\begin{array}{c}\text { Basal } \\
\text { Application } \\
\text { (A) }\end{array}$ & 3 & $* *$ & $* *$ & $* *$ & $* *$ & $* *$ & $* *$ \\
\hline $\begin{array}{c}\text { Spray } \\
\text { Application } \\
\text { (B) }\end{array}$ & 3 & $* *$ & $* *$ & $* *$ & $* *$ & $* *$ & $* *$ \\
\hline $\mathrm{AXB}$ & 9 & $* *$ & $* *$ & $* *$ & $* *$ & $*$ & $* *$ \\
\hline Error & 30 & 0.067 & 1.032 & 2.092 & 11.827 & ns & ns \\
\hline \multicolumn{2}{|c|}{$\mathrm{CV}(\%)$} & 1.12 & 0.7 & 4.16 & 0.73 & 6.42 & 7.67 \\
\hline
\end{tabular}

$*$ and ** show the least differences at 1 and 5 level of probability respectively and ns shows none significant difference.

Table 2. Comparison of the means of the data related to the addition of zinc, manganese, and boron to the soil on seed oil and protein, yield, and number of Pod

\begin{tabular}{|c|c|c|c|c|c|c|}
\hline Treatment & Oil \% & $\begin{array}{l}\text { Oil Yield } \\
\text { (Kg.h) }\end{array}$ & $\operatorname{Pr} \%$ & $\begin{array}{c}\text { Pr Yield } \\
\text { (Kg.h) }\end{array}$ & $\begin{array}{c}\text { Pods per } \\
\text { Plant }\end{array}$ & $\begin{array}{c}\text { Seed Yield } \\
\left(\mathrm{g} \cdot \mathrm{m}^{-2}\right)\end{array}$ \\
\hline Control & $22.23 \mathrm{D}$ & $249.64 \mathrm{D}$ & $35.09 \mathrm{AB}$ & $394.06 \mathrm{D}$ & $55.14 \mathrm{~B}$ & $112.3 \quad \mathrm{D}$ \\
\hline $\mathrm{Zn}$ to Soil & $22.73 \mathrm{C}$ & $321.85 \mathrm{~B}$ & $35.45 \mathrm{~A}$ & $501.97 \mathrm{~B}$ & $66.79 \quad \mathrm{~A}$ & $141.6 \mathrm{~B}$ \\
\hline Mn to Soil & $23.50 \mathrm{~B}$ & $359.31 \mathrm{~A}$ & $35.68 \mathrm{~A}$ & $545.54 \mathrm{~A}$ & $71.05 \quad \mathrm{~A}$ & $152.9 \quad \mathrm{~A}$ \\
\hline B to Soil & $23.99 \mathrm{~A}$ & $293.39 \mathrm{C}$ & $32.73 \mathrm{~B}$ & $400.28 \mathrm{C}$ & $57.04 \quad$ B & $122.3 \mathrm{C}$ \\
\hline $\operatorname{LSD}(0.05)$ & 0.431 & 41.12 & 2.412 & 5.735 & 6.68 & 5.91 \\
\hline
\end{tabular}

Numbers having common letters in each column are not significantly different at the probability level of 5 percent.

Table 3. Comparison of the means of the data related to spraying the micronutrients zinc, manganese, and boron on seed oil and protein, yield, and number of Pod

\begin{tabular}{|c|c|c|c|c|c|c|}
\hline Treatment & Oil \% & $\begin{array}{l}\text { Oil Yield } \\
\text { (Kg.h) }\end{array}$ & $\operatorname{Pr} \%$ & $\begin{array}{c}\text { Pr Yield } \\
\text { (Kg.h) }\end{array}$ & $\begin{array}{c}\text { Pods per } \\
\text { Plant }\end{array}$ & $\begin{array}{l}\text { Seed Yield } \\
\quad\left(\mathrm{g} \cdot \mathrm{m}^{-2}\right)\end{array}$ \\
\hline Control & $21.69 \mathrm{D}$ & $255.29 \mathrm{C}$ & $33.57 \mathrm{~B}$ & $395.11 \mathrm{D}$ & $56.64 \mathrm{C}$ & $117.7 \quad \mathrm{D}$ \\
\hline Zn Foliar & $25.03 \mathrm{~A}$ & $366.18 \mathrm{~A}$ & $33.24 \mathrm{~B}$ & $528.43 \mathrm{~A}$ & $68.33 \quad \mathrm{~A}$ & $146.3 \mathrm{~A}$ \\
\hline Mn Foliar & $22.94 \mathrm{C}$ & $317.71 \mathrm{~B}$ & $36.02 \mathrm{~A}$ & 498.87B & $65.81 \mathrm{AB}$ & $138.5 \quad \mathrm{~B}$ \\
\hline B Foliar & $23.78 \quad \mathrm{~B}$ & $300.81 \mathrm{~B}$ & $36.12 \mathrm{~A}$ & $420.86 \mathrm{C}$ & $9.24 \mathrm{BC}$ & $126.5 \mathrm{C}$ \\
\hline $\operatorname{LSD}(0.05)$ & 0.431 & 41.12 & 2.412 & 5.735 & 6.68 & 5.91 \\
\hline
\end{tabular}

Numbers having common letters in each column are not significantly different at the probability level of 5 percent. 


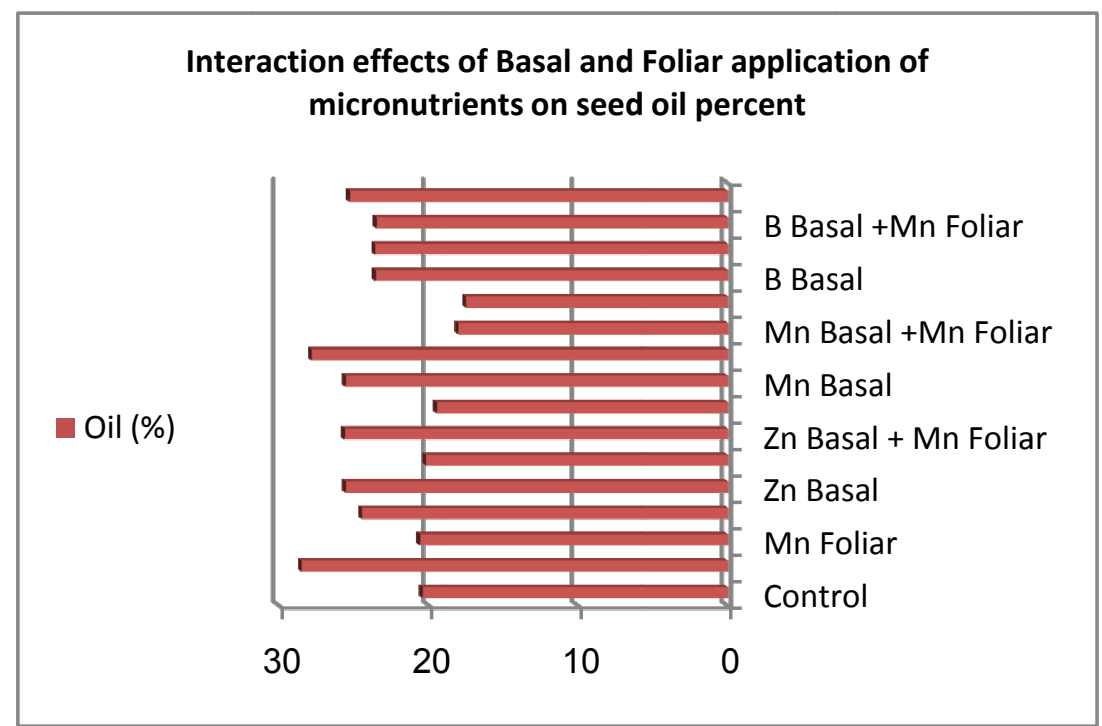

Figure 1. Interaction effects of Basal and Foliar application of micronutrients on seed oil percent

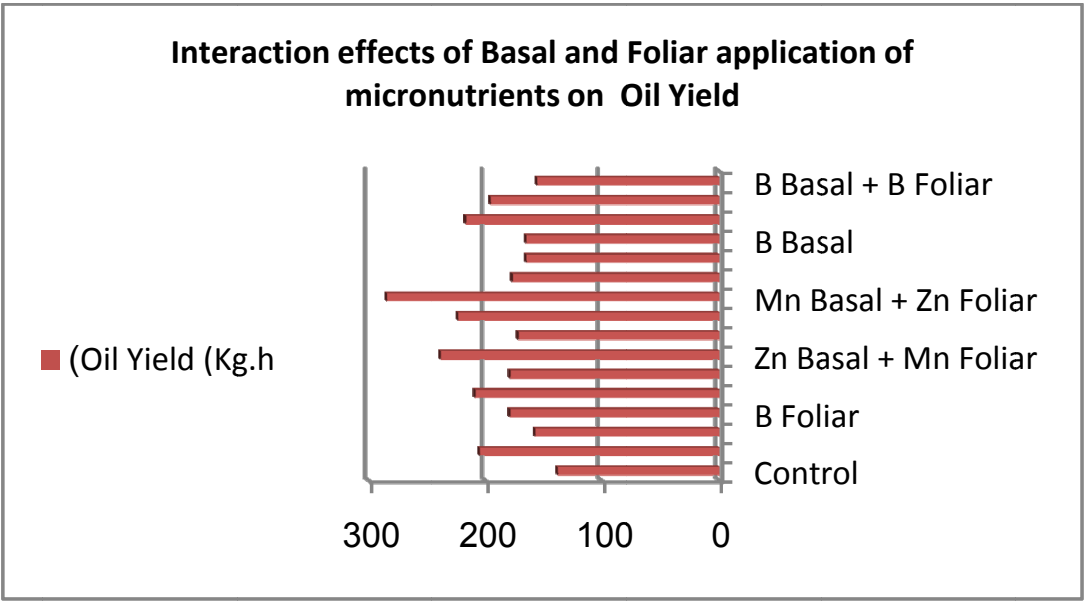

Figure 2. Interaction effects of Basal and Foliar application of micronutrients on oil yield

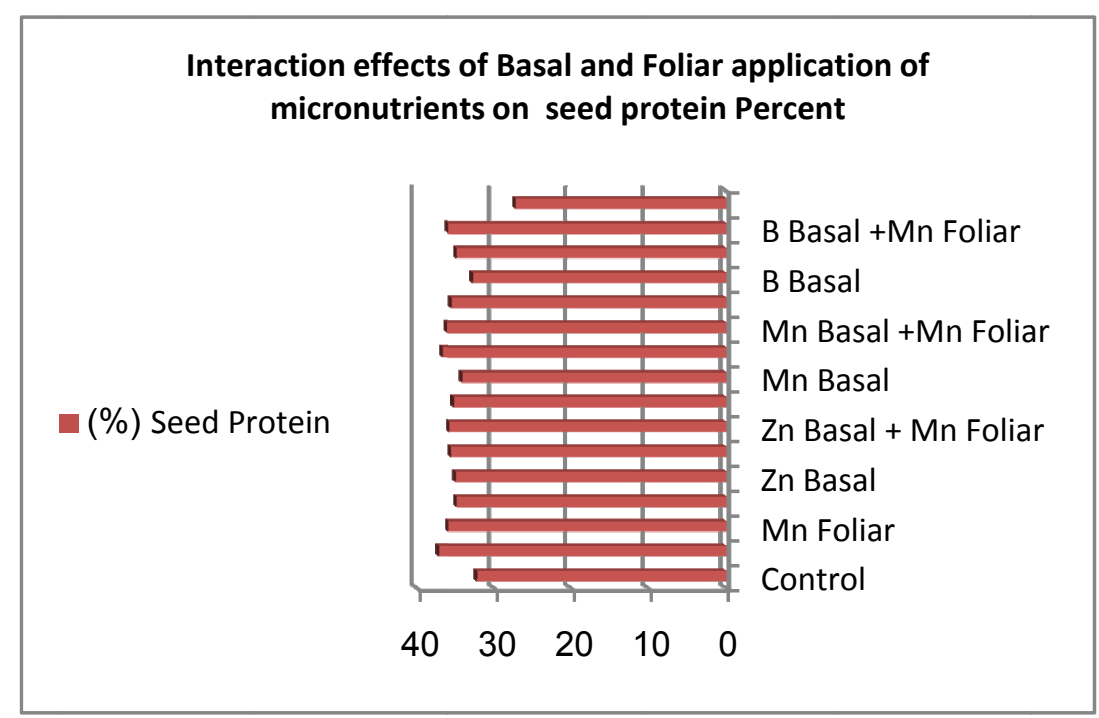

Figure 3. Interaction effects of Basal and Foliar application of micronutrients on protein percentage 


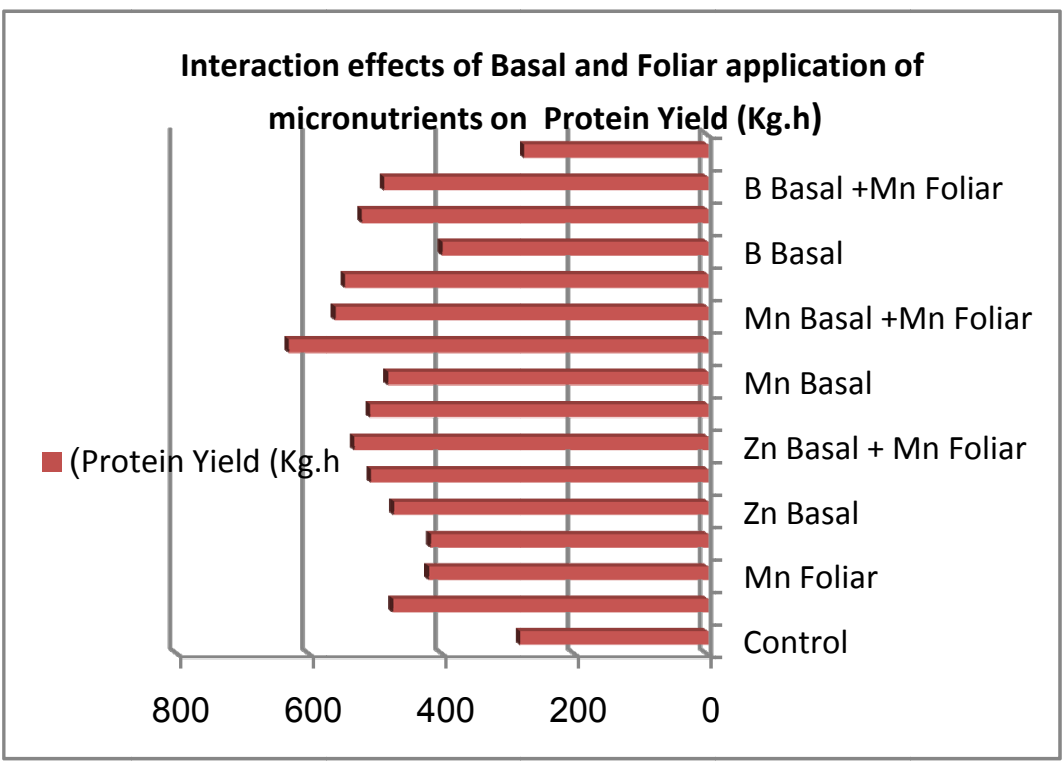

Figure 4. Interaction effects of Basal and Foliar application of micronutrients on protein yield

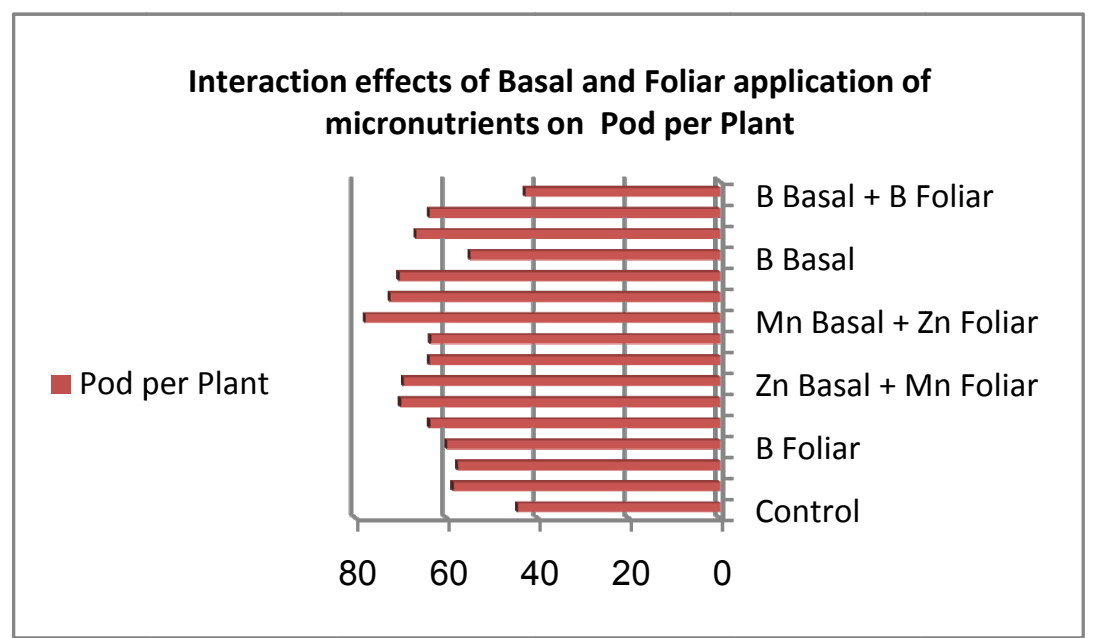

Figure 5. Interaction effects of Basal and Foliar application of micronutrients on number of pod per plant

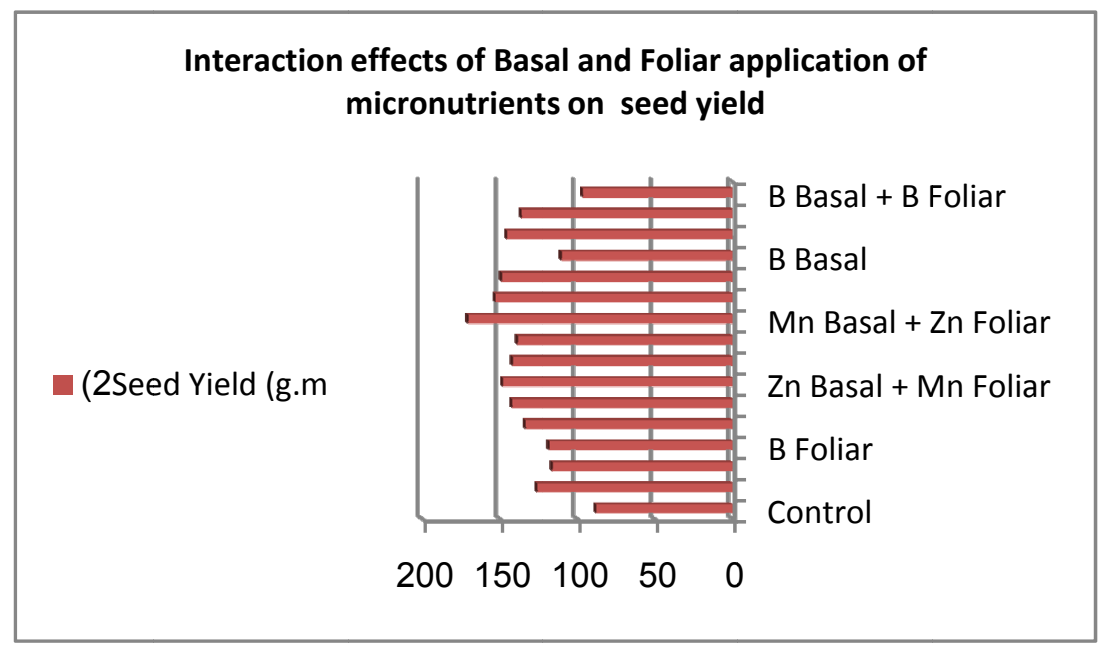

Figure 6. Interaction effects of Basal and Foliar application of micronutrients on seed yield 